\title{
An Application of Flipped Classroom Method in the Instructional Technologies and Material Development Course
}

\author{
İlknur Özpinar ${ }^{1}$, Arzu Aydoğan Yenmez ${ }^{1}$, Semirhan Gökçe² \\ ${ }^{1}$ Department of Mathematics and Science Education, Ömer Halisdemir University, Niğde, Turkey \\ ${ }^{2}$ Department of Computer Education and Instructional Technology, Ömer Halisdemir University, Niğde, Turkey \\ Correspondence: İlknur Özpinar, Faculty of Education, Ömer Halisdemir University, Niğde, Turkey.
}

Received: November 10, 2016

Accepted: November 29, $2016 \quad$ Online Published: November 29, 2016

doi:10.11114/jets.v4i12.1934

URL: http://dx.doi.org/10.11114/jets.v4i12.1934

\begin{abstract}
A natural outcome of change in technology, new approaches towards teaching and learning have emerged and the applicability of the flipped classroom method, a new educational strategy, in the field of education has started to be discussed. It was aimed with the study to examine the effect of using flipped classroom method in academic achievements and motivations of students and reveal the student opinions. The quasi-experimental method was used in this study and the participants were 50 sophomores that studying Elementary Mathematics Education in a state university. The results of the study shows that flipped classroom method does not have a significant effect on improving students' perceptions of technology use, and the students in the experimental group were more successful and had higher levels of motivation than the students in the control group. It was also revealed that the students had positive thoughts about the implementation of flipped classroom method.
\end{abstract}

Keywords: flipped classroom, pre-service teachers, instructional technologies, mathematics education, training videos

\section{Introduction}

In this era, social change and improvement is gaining momentum gradually and information and communication technologies are affecting every moment of individuals' lives. Starting to use technology intensively in every field of life has changed the priorities, lifestyles, and ways of thinking and learning needs of the new generation to change drastically compared to the older generations. Great differences are observed between the new generation and the previous one in terms of studying, doing homework, reading and communicating with the surroundings. One of the most important reasons is the use of technology (Bergmann \& Sams, 2012; Gençer, 2015; Ministry of National Education [MoNE], 2013; Temizyürek \& Ünlü, 2015). As a result, these developments have differentiated the student profile and the outputs expected from education (Turan, 2015), and as its natural consequence, educational systems have been affected by this change and improvement and the use of technology in education have become widespread (MoNE, 2013).

Today, not only the transfer of knowledge but also its construction has been made the central point of education. The technology having become widespread has facilitated the course contents to be taken out of the course and the students have been provided with the opportunity to reach the information independently from time and environment (Turan, 2015). Since students come to the classroom with emerging technological tools and new skills in the field each year, it is obvious that the interest and participation of those students, who have been accustomed to technology, will not be on the expected level when it comes to the use of traditional methods in the educational-instructional process. From another point of view, the use of methods through which students will be active in accordance with the technological developments in the classroom setting will affect the interest, participation and the achievement level of the students (Bergmann \& Sams, 2012; Kaya \& Aydın, 2011; Tarman \& Baytak, 2011). Accordingly, new approaches towards teaching and learning have emerged, and the applicability of flipped classroom method, a new educational strategy, in education has become a current issue (Bergmann \& Sams, 2012).

Bishop and Verleger (2013) stated that the flipped classroom method allows students to access the parts of the subjects in the courses they will study appropriate for individual learning outside the school and provide them with the chance to perform problem solving activities about those subjects rather individually or in group in the classroom setting. In the flipped classroom method, students do not learn the course in the classroom but before coming to the classroom. 
Teachers just share open educational sources or the materials related to the course by digital platforms. Then, the students access and study the subject and perform activities of the course before the class independently from time and space through the sharing under the guidance of their teachers and they take down notes about the issues they have problem with and report them to their teachers. The teacher can take the points which the students did not understand into account by dividing them into groups so that they can discuss within classroom activities. This contributes to the development of students' problem solving and analytical thinking skills.

The flipped classroom method is not only about the courses taught in the company of video recording; the point is the significant and interactive activities performed in the classroom (Bergmann \& Sams, 2012). In other words, this method, which allows students to focus on the problems they encounter during the individual learning, is defined as the replacement of in-class teaching with homework (Abeysekera \& Dawson, 2015; Chen, Wang \& Chen, 2014; Gençer, 2015; Johnson \& Renner, 2012; Milman, 2012; Kim, Kim, Khera, \& Getman,2014; Sarıtaş \& Yıldız, 2015; Talbert, 2012; Bishop \& Verleger, 2013).

One of the most important advantages of flipped classroom method is the efficient use of time. In the traditional instruction, teachers spare most of their time in the classroom for lecturing whereas, in the flipped classroom method, they reinforce the efficiency of students' learning by guiding (Bergmann \& Sams, 2012; Miller, 2012; Talbert, 2012; Touchton, 2015). The flipped classroom method provides time and space flexibility to the students and helps them to learn in accordance with their individual paces (Bergmann \& Sams, 2012). Since students are already prepared when they come to the classroom, their participation in the classroom activities becomes easier, their communication with their peers and teachers is enhanced due to the interaction, they feel more comfortable because they know, they can get immediate and direct help even in the most difficult activities, and they get the chance to know themselves better and assume the responsibility of their learning because they are now more active (Bergmann \& Sams, 2012; Kim et al., 2014; Miller, 2012; Talbert, 2012, Touchton, 2015; Zownorega, 2013). There are also some disadvantages of the flipped classroom method. These include that it is difficult for students who are accustomed to learning though traditional methods, that students do not want to assume more responsibility for their learning since it's their responsibility of watching the videos before the class. Also the videos may have lower quality, and students need more individual effort in order to understand the videos. Moreover, students have no opportunity to ask peers or teachers questions immediately since the videos are watched alone. In addition, teachers cannot be ready to apply this method or can find it troublesome (Miller, 2012; Milman, 2012; Talbert, 2012).

The flipped classroom method has become popular in the educational setting (Tucker, 2012). There are several studies on the flipped classroom method in which the opinions and perceptions of students and teachers are examined (Butt, 2014; Gençer, 2015; Johnson, 2013; Bishop \& Verleger, 2013; Görü Doğan, 2015; Osman, Jamaludin \& Mokhtar, 2014; Turan \& Göktaş, 2015) and the effect of the flipped classroom method on the student achievement and motivation (Aşıksoy \& Özdamlı, 2016; Baepler, Walker \& Driessen, 2014; Davies, Dean \& Ball, 2013; Gençer, 2015; Johnson \& Renner, 2012; Moravec, Williams, Aguilar-Roca \& O’Dowd, 2010; Talbert, 2012). When the studies in Turkey are examined, it is seen that there are limited number of studies on this subject (Aşıksoy \& Özdaml1, 2015; Gençer, 2015; Görü Doğan, 2015; Temizyürek \& Ünlü, 2015; Turan, 2015; Turan \& Göktaş; 2015).

Aşıksoy and Özdamlı (2015) aimed at determining the effect of the flipped classroom method on the achievement, motivation and self-efficacy of students in the physics class by adapting Keller's ARCS (Attention, Relevance, Confidence and Satisfaction) Motivation Model. The study in question was conducted with the sophomores who were the students of the Computer Education and Instructional Technologies Program and the students were separated into control and experimental groups. The flipped classroom method was used in the experimental group while the traditional methods were utilized in the control group, and the research findings showed that the students in the experimental group were more successful, their levels of motivation and self-efficacy were enhanced and they had positive thoughts about the flipped classroom method. Gençer (2015) discussed that how the flipped education model can be applied in the Turkish Educational System and conducted a case study at a school which uses it in accordance with its systematical definition. It was concluded as a result that the efforts such as doing research about learning the model and preparing and presenting the course materials to students, etc. increased the workload of teachers but the model was accepted and contributed to student achievement significantly because it allowed students to play active roles, take the responsibility of individual learning and spare more time for in-class activities within the scope of applying the flipped classroom model. In her study in which she focused on how social media can be used more efficiently and productively in the learning processes within the framework of the flipped learning approach, Görü Doğan (2015) aimed at examining the experiences of learners about supporting a mandatory and formal university course with social media and the opinions on how this course is taught with the flipped learning approach. Similarly, Turan and Göktaş (2015) tried to determine students' opinions on the flipped classroom method in their study. They conducted the study within 10 weeks with the students at the department of Early Childhood Education. As a result, it 
was seen that the students had quite positive thoughts about the flipped classroom method. The students reported that the flipped classroom method is a fun and flexible method which enhances the permanence of learning and facilitates learning. In addition, they stated that the flipped classroom method has some disadvantages such as lack of technical tools, the fact that the method is very time-taking and videos need to be watched before the class as well as several advantages of its. In their study aiming to give information about the concept and applications of the flipped classroom and perform a field review about how it can be used in the instruction of foreign languages, Temizyürek and Ünlü (2015) examined the studies on the subject both domestically and abroad and reviewed the effectiveness of the applications, revealing the benefits of using this method in the language classes. Turan (2015) conducted a study with the students of a Early Childhood Education which aimed at determining the effect of the flipped classroom method on the academic achievement, cognitive load and motivation and revealing the student opinions on the method. According to the findings obtained in the study, the students who studied with the flipped classroom method had higher levels of achievement and motivation and lower levels of cognitive loads than those who studied with the traditional method. In addition, it was revealed that the students had positive opinions on the flipped classroom method.

In general, the courses are taught at universities with traditional methods including the presentation of the course content by the instructor, students taking notes and working on homework, projects and other activities outside the classroom setting. It is difficult to design instruction differently in traditional classrooms. Yet, it is obvious that this order, which has survived to date, may not the best solution for learning. Instead of benefiting from their teachers at maximum in the classroom, students do not need much help at the moment because cognitive activities are scarce in the classroom in traditional instructional methods. On the other hand, the activities at which students have difficult the most are the activities they perform on their own without the help of their teachers outside the classrooms. It is seen as an improvement to flip this order-by ensuring that basic information is taught via courses, reading and additional sources outside the classroom. Although there are potential problems, it is obvious that the flipped classroom method may make the courses at university more interactive, inclusive and efficient. When considering that the current technology helps today's students via natural learning, it is thought to be right to try to move traditional classrooms into the flipped classroom method (Talbert, 2012).

Nowadays, in a period in which technology has reached a dazzling level, new information, our perspective of mathematics together with opportunities and instruments, our expectations from mathematics, our way of using mathematics and, more importantly, our processes of learning and teaching mathematics have been reshaped and had their share of this change. In today's world where different problems that have not been faced by previous generations in accordance with technological developments, the need for individuals who appreciates the value of mathematics, whose mathematical thinking is powerful and who can use mathematics in modeling and problem-solving is also increasing (MoNE, 2013). Raising individuals who are qualified to meet the needs of the century we are in is primarily among the responsibilities of the institutions of education. Thus, it is important for schools to transform the traditional structure into a new construct that will attract students' attention even more through technological facilities without restricting learning process (Demiralay \& Karataş, 2014). The importance of the task taken on by teachers for technology to be used in education effectively and efficiently, that is, in ensuring the technological integration in education cannot be underestimated. Indeed, teachers are included, without no doubt, in the most important elements to lead the changes in educational settings. Accordingly, students of elementary mathematics education receive several courses regarding the use of technology along their educations because they are the individuals who will bring the technology into the classroom setting in general and they will integrate the technology into the mathematical instruction in particular. The "Instructional Technologies and Material Development" course is among the courses within this scope which are taken by pre-service teachers to ensure the technological integration and develop their teaching skills. In general, it is aimed in this course that pre-service teachers are informed of technological developments, can use technology and acquire the ability to develop new materials by using technology and environment, etc. (Alım, 2007). When the literature is examined, there are studies revealing that pre-service teachers graduate from the faculties of education without acquiring the sufficient knowledge and skill on how they can use the instructional technologies at their classes and therefore they have shortcomings in the instructional processes or they do not use them by showing resistance and find themselves incompetent (Adigüzel \& Yüksel, 2012; Asan, 2002; Doğan \& Yılmaz, 2012; Küçükahmet, 2002; Taş̧̧1, Yaman \& Soran, 2010; Toptaş, Çelik \& Karaca, 2012). One of the reasons for these problems seems to be that there is not enough time for both lecturing and practicing during the class hour. Indeed, it is thought that sparing more time for activities in the classroom setting is of value in relation to raising more qualified teachers on the related subject since it is important to do practice as much as the knowledge itself. In addition, it is thought that there are shortcomings regarding this need, thus this study will contribute to the literature when considering the studies conducted with the flipped classroom method in Turkey. Therefore, based on the idea that the flipped classroom method may solve the problem, it is aimed in the research to examine the effect of the flipped classroom method on the academic achievement and motivation of the students of elementary mathematics education program and determine the student opinions on the method. 


\section{Method}

The quasi-experimental method was used in the study. Before the application, the students were divided into the experimental ad control groups according to their academic achievement scores. There were 25 students in each of the groups.

\subsection{Participant}

The subject of the research was composed of 50 sophomores who were attending at the Elementary Mathematics Education Program in the Faculty of Education of a state university in the spring term of the academic year of 2015-2016.

\subsection{Data Collection Instruments and Data Analysis}

In the study, The Basic Technology Competencies Scale for Educators Inventory, the Technological Perception Scale, the Instructional Material Motivation Survey, and an Achievement Test with open-ended questions which was prepared in accordance with the expert opinions were used as data collection instruments.

\subsubsection{Basic Technology Competencies Scale for Educators Inventory}

The Basic Technology Competencies Scale for Educators Inventory was developed by Flowers and Algonizze (2000) to examine students' technological competencies and its validity and reliability studies were performed by Tekinarslan (2008) in Turkey. The 4- point Likert type scale (Not Competent:1, Somewhat Competent:2, Competent:3 and Very Competent:4) is composed of 9 subdimensions (Basic Computer Operations Skills, Setup, Maintenance and Troubleshooting of Equipment, Word Processing, Spreadsheets, Databases, Networking, Telecommunications, Media Communication [Electronic Slide, Overhead Projector, etc.], and Social, Legal and Ethical Issues) and 48 items. Lower scores obtained from the scale and scale's subdimensions indicate lower levels of competency while higher scores prove higher levels of competency. The Cronbach's Alpha internal consistency coefficient for the whole scale was calculated to be .95 by Tekinaraslan (2008) whereas it was calculated to be .97 in this study.

\subsubsection{Technological Perception Scale}

This is a 5-point Likert type scale (Strongly Disagree, Disagree, Neutral, Agree, Strongly Agree) which was developed by Tinmaz (2004) to measure students' perceptions of using technology in education and it is composed of two factors (Belief in the Positive Effect of Technology in Education and the Effect of Technology on the Undergraduate Program) and 28 items. According to the validity and reliability study performed by Tınmaz (2004), Cronbach's Alpha coefficient of the scale was found to be .86 whereas it was calculated to be .90 in this study.

\subsubsection{Instructional Material Motivation Survey}

In order to measure the effect of the flipped classroom method used in the study on student motivation, Instructional Material Motivation Survey (IMMS) which was developed by Keller (1993) and adapted into the Turkish language by Acar (2009) was used in the study. The IMMS is a 5-point Likert type survey composed of 36 items. Students answer each item by grading from 1 (Not True) to 5 (Very True) in the survey. The lowest score that can be obtained in the survey is 36 and highest one is 180. The Cronbach's Alpha internal consistency coefficient for the whole scale was calculated to be .92 by Acar (2009) whereas it was calculated to be .84 in this study.

\subsubsection{Achievement Test}

The Achievement Test developed with the opinions of four experts to determine if the students of the experimental and control groups are cognitively equivalent is composed of 10 open-ended questions. The literature was taken into consideration for evaluating the questions in the Achievement Test (Akpınar \& Ergin, 2005; Aşçı, Özkan\&Tekkaya, 2001; Bayram, Sökmen \& Savc1, 1997; Coştu, Ünal \& Ayas, 2007) and, as seen in Table 1, the answers (correct, partly correct, incorrect and unanswered) were examined and graded under four categories.

Table 1. Evaluation and grading criteria of the questions in the Achievement Test

\begin{tabular}{lll}
\hline Categories & Contents & Score \\
\hline Correct & Answers involving all of the correct ideas with scientific explanations & 10 \\
Partially Correct & Answers which are not the exact ones to the question but acceptable & 5 \\
Incorrect & Answers lack of any scientific value and less related to the question & 0 \\
Missing & Answers in which the whole or part of the question is repeated or which were left blank & 0 \\
\hline
\end{tabular}

Each of the questions in the test are 10 points and the scores obtained by each student were calculated over 100 points.

\subsubsection{Questionnaire}

When preparing the questionnaire, it was made sure that the questions would be open ended and easily understandable, not manipulate students, not be multi-dimensional and be organized reasonably (Yıldırım \& Şimşek, 2006) and the 
opinions of four experts were received. There are questions addressing the subjects "opinions on the videos prepared, purposes of watching the videos and suggestions on this, strengths-weaknesses of the method applied, factors increasing-decreasing the motivation, and applicability of the method."

Basic Technology Competencies Scale for Educators Inventory, Technological Perception Scale and the Achievement Test was applied to both groups (experimental and control) before the application. Technological Perception Scale and the Achievement Test were applied to both groups again after the experimental procedure. Instructional Material Motivation Survey was performed for the motivation variable at the end of the application. Later, qualitative data was collected via the questionnaire distributed to the students. The procedure applied to the experimental and control groups within the scope of the research are given in detail in the following table.

Table 2. Research design

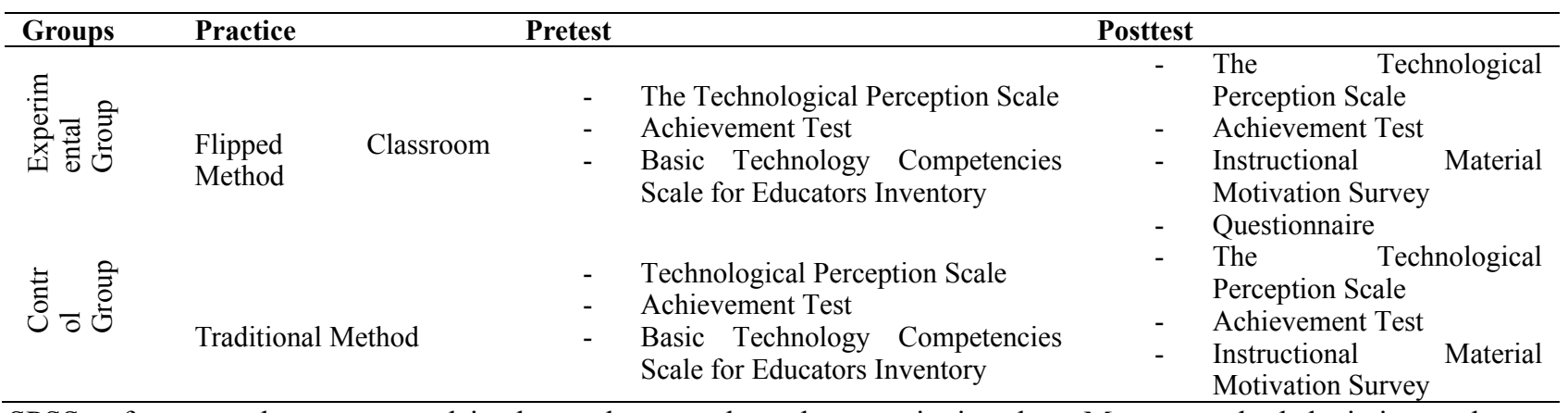

SPSS software package was used in the study to analyze the quantitative data. Mean, standard deviation and t-test outputs were utilized in the analysis of quantitative data. The qualitative data were subjected to a content analysis and were mentioned as direct citations regarding the coding along with the frequency and percentage values.

\subsection{Implementation Process}

In the research conducted within the scope of the Instructional Technologies and Material Development course, the students were informed of the study and their questions were answered before the application. Next, Basic Technology Competencies Scale for Educators Inventory, Technological Perception Scale and the Achievement Test were applied to both groups as pretests. As a result of analyzing the scores of the Achievement Test applied to the students before the procedure, it was seen that there was no difference between the groups. It was assumed that the groups were equal because there was no significant difference between the mean scores of Achievement Test.

Before starting the eight-week implementation, in consideration of the class hour, content and requirements of the Instructional Technologies and Material Development course, the procedures, which were set forth for the courses to be taught in accordance with a certain program, were determined and the instruments to be used during the class along with the video of each week according to that program were prepared.

Table 3. Activities in experimental and control groups and their durations

\begin{tabular}{|c|c|c|c|}
\hline Control Group & & Experimental Group & \\
\hline Efficiency & $\begin{array}{l}\text { Duration } \\
\text { (min.) }\end{array}$ & Efficiency & $\begin{array}{l}\text { Duration } \\
\text { (min.) }\end{array}$ \\
\hline $\begin{array}{l}\text { Introduction (warm-up) activities (Detection } \\
\text { of the preparedness and examination of the } \\
\text { homework done) }\end{array}$ & $20-40$ & $\begin{array}{l}\text { Introduction (warm-up) activities (Short } \\
\text { repetition of the previous subject with } \\
\text { the videos) }\end{array}$ & 10 \\
\hline Lecturing by the instructor & $60-90$ & Videos & 40 \\
\hline $\begin{array}{l}\text { Summarizing the subject and asking the } \\
\text { evaluating questions regarding the subject at } \\
\text { the end of the class }\end{array}$ & 10 & $\begin{array}{l}\text { Answering the questions regarding the } \\
\text { subjects in the video and in-class } \\
\text { independent activities ( problem solving, } \\
\text { discussions, practices, question-answer } \\
\text { in groups, etc.) under the guidance of the } \\
\text { instructor }\end{array}$ & 90 \\
\hline
\end{tabular}

In the courses in the control group taught with the traditional instructional method applied in the classroom habitually and constantly, the instructor lectured the course content theoretically and then the students prepared the technology-aided and concrete material activities as homework to present them. The students in the experimental group learned the content of the same course based on the flipped classroom method. The instructor recorded 40-minute videos involving the subjects of the course content before the class and gave the videos to the students a week before the courses (see Figure 1). The students watched the videos and took down notes about important points and what they had not understood. During the implementation, in-class activities such as homework or projects about the course 
content were included with the help of the instructor. The activities performed in the experimental and control groups and their durations are given in Table 3.

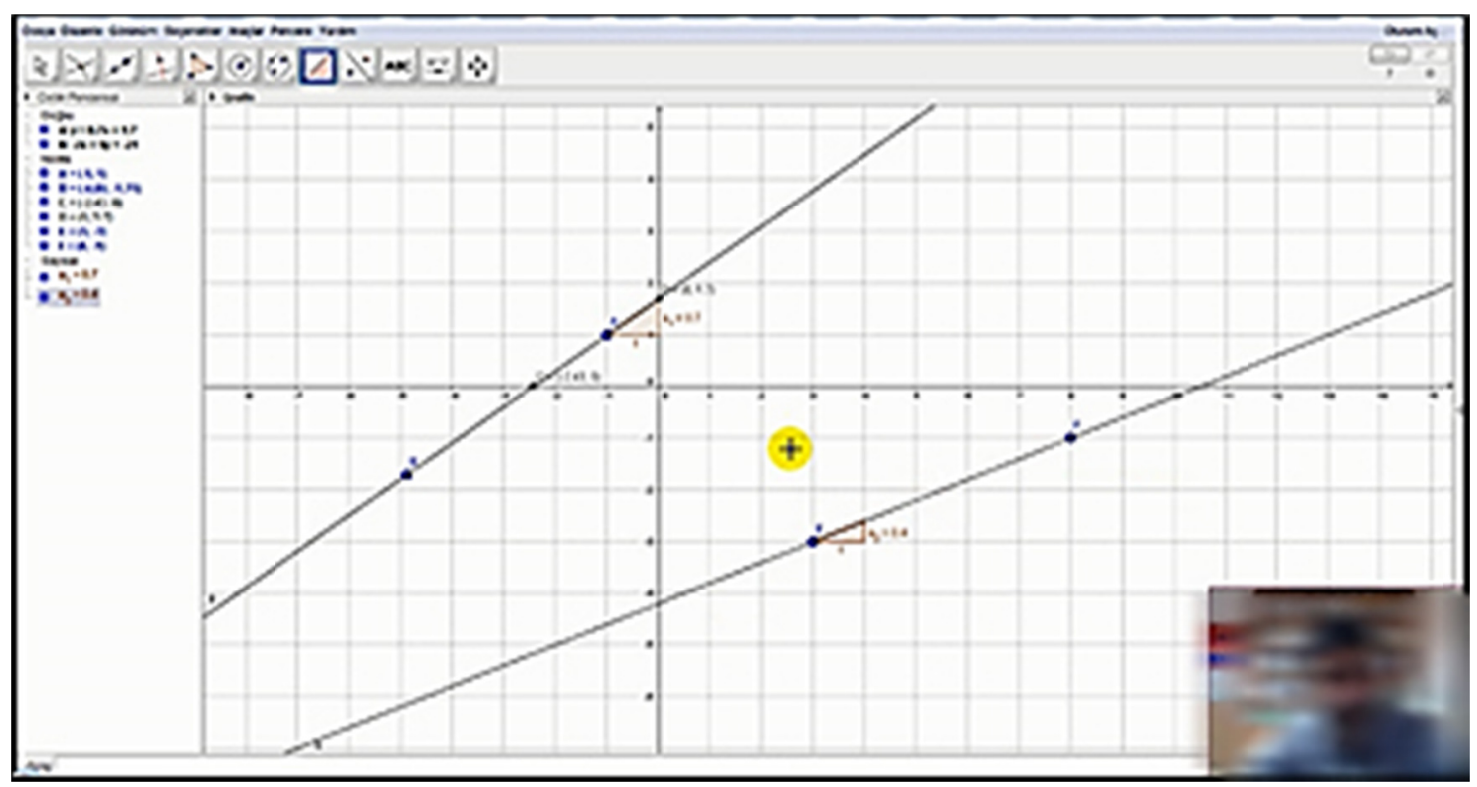

Figure 1. An exemplified screenshot of the GeoGebra training videos

At the end of the procedure, Technological Perception Scale, Instructional Material Motivation Survey and the Achievement Test were applied to the students as posttest and the questionnaire prepared was distributed to them. During the data analysis, the participants were coded as S1, S2, S3, ... so that the students can be distinguished.

\section{Results}

The findings obtained in the data analysis are gathered under subheadings in this section.

\subsection{Findings related with the Scales Applied}

In this study aiming to examine the effect of the flipped classroom method on the academic achievement and motivation of students and determine the student opinions on the method, Basic Technology Competencies Scale for Educator Inventories was applied as a pretest, Instructional Material Motivation Survey was applied as a posttest, and the Technological Perception Scale and the Achievement Test were applied as both pretests and posttests to the students. Results regarding Basic Technology Competencies Scale for Educator Inventories are given in Table 4.

Table 4. Independent variables t-test results regarding the scores in the Basic Technology Competencies Scale for Educator Inventories

\begin{tabular}{lllllll}
\hline Group & N & $X$ & S & sd & t & p \\
\hline Control & 25 & 2.89 & .54 & 48 & .17 & .869 \\
Experimental & 25 & 2.86 & .46 & & & \\
\hline
\end{tabular}

It is seen in Table 4 that there is no significant difference between the groups in regard to the scores they obtained in the basic technology competencies scale $\left(t_{(48)}=.17, \mathrm{p}>.05\right)$.

The results of the t-test performed for the significance of the difference between the technological perception scores of the students in the experimental and control groups are given in Table 5 and Table 6.

Table 5. T-test results of the Technological Perception Scale pretest scores by groups

\begin{tabular}{lllllll}
\hline Group & N & $X$ & S & sd & t & p \\
\hline Control & 25 & 4.11 & .34 & 48 & 1.52 & .136 \\
Experimental & 25 & 3.96 & .35 & & & \\
\hline
\end{tabular}

Table 5 shows that there is no significant difference between the groups in terms of the technological perception pretest scores $\left[\mathrm{t}_{(48)}=1.52, \mathrm{p}>.05\right]$. The Technological Perception Scale pretest score average of the control group students is $\bar{X}$ $=4.11$, the score average of the experimental group students is $\bar{X}=3.96$ for the same test. This finding indicates that there is no difference between students' perceptions of using technology before the procedure. 
Table 6. T-test results of the Technological Perception Scale posttest scores by groups

\begin{tabular}{lllllll}
\hline Group & N & $X$ & S & sd & t & p \\
\hline Control & 25 & 4.08 & .38 & 48 & .24 & .813 \\
Experimental & 25 & 4.06 & .32 & & & \\
\hline
\end{tabular}

It was found that there was no significant difference between groups in terms of the Technological Perception Scale posttest scores by the method applied $\left[\left[\mathrm{t}_{(48)}=.24, \mathrm{p}>.05\right]\right.$. It is seen in Table 6 that the students in both experimental and control groups had the same score averages in the Technological Perception Scale. This finding indicates that the method applied is not an important factor in students' perceptions of using technology.

Table 7. Results of independent samples t-test regarding the Instructional Material Motivation Survey scores

\begin{tabular}{lllllll}
\hline Group & $\mathbf{N}$ & $X$ & S & sd & t & p \\
\hline Control & 25 & 3.55 & .30 & 48 & 2.16 & .036 \\
Experimental & 25 & 3.77 & .40 & & & \\
\hline
\end{tabular}

According to Table 7, there is a significant difference between the groups in terms of the scores they obtained in the Instructional Material Motivation Survey $\left(\mathrm{t}_{(48)}=2.16, \mathrm{p}<.05\right)$. The students in the experimental group had higher levels of motivation $(\bar{X}=3.77)$, than those in the control group $(\bar{X}=3.55)$.

Table 8 . T-test results of the Achievement pretest scores by groups

\begin{tabular}{lllllll}
\hline Group & N & $X$ & S & sd & t & p \\
\hline Control & 25 & 21.60 & 8.26 & 48 & .83 & .411 \\
Experimental & 25 & 19.60 & 8.77 & & & \\
\hline
\end{tabular}

Table 8 shows that there is no significant difference between the groups in terms of the achievement pretest scores $\left[\mathrm{t}_{(48)}=83, \mathrm{p}>.05\right]$. According to Table 8 , the score average of the control group students obtained in the achievement pretest is $\bar{X}=21.60$ and the score average of the experimental group students obtained in the same test is $\bar{X}=19.60$. This finding indicates that there is no difference between the groups in regard to the levels of academic achievement.

Table 9. T-test results of the Achievement posttest scores by groups

\begin{tabular}{lllllll}
\hline Group & N & $X$ & S & sd & t & p \\
\hline Control & 25 & 57.40 & 10.52 & 48 & 2.42 & .019 \\
Experimental & 25 & 64.00 & 8.66 & & & \\
\hline
\end{tabular}

It is understood from Table 9 that students' achievement posttest scores differed by the method applied $\left[\left[\mathrm{t}_{(48)}=2.42\right.\right.$, $\mathrm{p}<.05]$. The achievement posttest score averages of the students in the control and experimental groups are 57.40 and 64.00 respectively. This finding indicates that the method applied is an important factor in students' academic achievement levels.

\subsection{Student Opinions on the Flipped Classroom Method}

Students' opinions on the application procedure and the flipped classroom method were obtained with the questionnaire. The following findings were achieved as a result of the analysis of the data.

First of all participants were asked to tell about their opinions on the videos prepared for the course. It was observed that majority of them agreed that the videos were appropriate for the level, understandable and detailed. In addition, 16 students reported that there was a problem with the synchrony of sound and image but they overcame this problem. The student opinions on this topic are as follows:

"In the last video, the teacher narrates but the footage is following the voice. That's why it was hard to understand it. I took notes by watching the footage; I tried to overcome the problem this way." (S1)

"I liked the videos in general. Our teacher was lecturing nicely and in a detailed and applied way. The lengths of the videos were also enough. I just face one trouble. It was that voice of the teacher in the video was ahead of the image. I just listened to the teacher instead of watching the footage and overcome the problem. " (S7)

"Videos were so beautiful. The teacher being in the footage and lecturing and how we put the lecturing into practice were so fun [...] It was good to take the class in an applied way and with the voice of the teacher. The only problem was that I had a bit difficulty because the voice and the footage were asynchronous [...]" (S18)

The students stated that the reasons why they watched the videos were to learn better (S1, S2, S3, S9, S14, S12, S11, S23, S24 and S25), to be able to do homework of better quality (S2, S3, S6, S10, S19 and S21), the curiosity and desire to learn about the subject (S4, S7, S11, S12, S16 and S17), to feel responsible (S8, S21 and S23), to learn a new method that can be used in their professional development (S22 and S23) and to find the course fun (S8).

The students also mentioned about the advantages and disadvantages of the flipped classroom method compared to the traditional methods applied in the classes habitually and constantly. Student opinions on the flipped classroom method's advantages are given in Table 10 . 
Table 10. Frequency of the advantages of flipped classroom method

\begin{tabular}{lll}
\hline Codes & $\mathbf{f}$ & \% $^{*}$ \\
\hline Ensuring active participation in the process & 19 & 76 \\
Enhancing the student-teacher interaction & 19 & 76 \\
Being a flexible method in terms of time and space & 18 & 72 \\
Allowing to watch repetitively & 18 & 72 \\
Enhancing the peer interaction & 17 & 68 \\
Ensuring a permanent learning & 15 & 60 \\
Being attractive and desirable & 10 & 40 \\
Ensuring the economic use of time & 8 & 32 \\
The fact that homework and issues that are not understood can be discussed in the & 6 & 24 \\
classroom & & 16 \\
Enabling the responsibility & 4 & 8 \\
Being based on practice & 2 & 4 \\
Ensuring that students come to the class as being prepared & 1 & 4 \\
Enhancing the cooperation & 1 & 4 \\
\hline
\end{tabular}

* Percentage values may exceed $100 \%$ because the answers of some of the students were placed under multiple codes.

According to Table 10, the most reported advantages of the flipped classroom method were "ensuring the active participation in the process", "enhancing the student-teacher interaction", "being a flexible method in terms of time and space", "allowing watching repetitively" and "enhancing the peer interaction". The exemplary opinions of the students on these codes are as follows:

"When I forgot something, I got to go back to the video and remember that. I was able to watch the video as much I wanted. I discussed the homework with my teacher and friends in the class and had many ideas." (S2)

"[...] I'm definitely more active. The reason is that I made an effort to clear up the points I had trouble with moment to moment. I got the chance to do practice more than enough. [...]"(S6)

"[...] I can say it's advantageous in the following manner: You have the opportunity to do practice when listening to the lecture. Otherwise, we may be missing something when listening to the teacher in the course taught with traditional methods. But there is no such problem in the flipped classroom method. You have the chance to watch the video again and again. And you can stop the video when you're bored or there is a problem." (S24)

Students reported that the flipped classroom method has disadvantages such as "not being able to receive immediate feedback", "mitigating the student-teacher interaction", "the responsibility of watching the videos before the class", "the fact that there is nothing to do in case of lack of instruments" and "limited time to prepare homework in the classroom". The percentage and frequency values of these codes are presented in Table 11.

Table 11. Frequency of the disadvantages of flipped classroom method

\begin{tabular}{lll}
\hline Codes & $\mathbf{f}$ & \% $^{*}$ \\
\hline Not being able to receive immediate feedback & 21 & 84 \\
Mitigating the peer interaction & 7 & 28 \\
Responsibility of watching the videos before the class & 3 & 12 \\
The fact that there is nothing to do in case of lack of instruments & 2 & 8 \\
Limited time to prepare homework in the classroom & 1 & 4 \\
\hline
\end{tabular}

* Percentage values may exceed $100 \%$ because the answers of some of the students were placed under multiple codes.

According to Table 11, the students mostly emphasized on "not being able to receive immediate feedback." The student thoughts regarding the disadvantages of the flipped classroom method are as follows:

"[...] If I did my homework at home, I would have as much time as I wanted. But I think the class hour is not enough for the activities in the classroom now. (S14)

"[...] Since we sometimes didn't have any other chance and the teacher wouldn't be able to lecture, it was hard to take on the obligation of watching videos at home and the responsibility of trying to learn on our own." (S16)

"I think its only negative aspect is that you can't ask the teacher any question or anything you don't understand at that moment."(S20)

Differently from other students, based on the disadvantage of "not being able to receive immediate feedback", it was remarkable that some students presented the opinion on the applicability of this method in different courses. Students stated that the flipped classroom method is not a suitable method for the branch courses as follows:

"[...] For example, this wouldn't work in the field courses. [...] It wouldn't work in the algebra or analysis class by any means. I wouldn't want it to work, indeed. It's very important to receive feedbacks in those classes." (SI6) 
"I think it isn't suitable for the field courses because we can't ask what we can't understand at once. But I find it suitable except for the field courses. It would be pretty good in the courses based on practice." (S22)

Another question asked to the students was about what are the factors increasing or decreasing their motivation in the flipped classroom method. Factors increasing students' motivations in the flipped classroom method are given in Table 12.

Table 12. Frequency of the factors increasing the motivation in the flipped classroom method

\begin{tabular}{lll}
\hline Codes & $\mathbf{f}$ & \%* \\
\hline Desire to learn and curiosity & 9 & 36 \\
Being able to watch whenever and wherever possible & 7 & 28 \\
Doing practice & 4 & 16 \\
The fact that it can be used in the occupational life & 4 & 16 \\
Being more active & 3 & 12 \\
The idea that the course will be more effective and there will be permanent learning & 2 & 8 \\
Coming to the class as prepared & 1 & 4 \\
The fact that group activities make the course more fun & 1 & 4 \\
Giving the chance to discuss & 1 & 4 \\
\hline
\end{tabular}

* Percentage values may exceed 100\% because the answers of some of the students were placed under multiple codes.

According to the table, the most prominent factors that increase the motivation are "desire to learn and curiosity", "being able to watch whenever and wherever possible", "doing practice" and "the fact that it can be used in the occupational life”. The student opinions regarding this finding are as follows:

"[...] The fact that I will be able to prepare the materials that will help us in our professional development. "(S10)

"[...] I think this method will be helpful in the future. Therefore, I care about it. It makes me curious.” (S21)

Majority of the students stated that there were no factors that decreased their motivations. Others reported factors decreasing the motivation such as "watching the videos individually", "not being able to ask questions immediately" and "long durations of video". Percentage and frequency values regarding these codes are shown in Table 13.

Table 13. Frequency of the factors decreasing the motivation in the flipped classroom method

\begin{tabular}{lll}
\hline Codes & f & \%* \\
\hline Watching videos individually & 3 & 12 \\
Not being able to ask questions immediately & 3 & 12 \\
Long durations of video & 2 & 8 \\
\hline
\end{tabular}

* Percentage values may exceed 100\% because the answers of some of the students were placed under multiple codes.

Additionally, most of the students emphasized on positive contribution of the group activities in the classroom to the fact that they can realize their shortcomings and shape their thoughts by exchanging ideas. The student opinions regarding this finding are as follows:

"The group homework in the traditional method isn't exactly group homework. In general, tasks are distributed and everyone completes a part of homework independently. But when it's in the classroom, everyone is doing the homework altogether and it's literally group homework, then.[...]" (S3)

"[...] I made a research about the homework given before and found ideas on my own. I couldn't find the chance the issues I had trouble with in the classroom. Because there were subjects to be taught in the classroom, I managed to get opinions about the homework outside the classroom. But, with this method, almost all of the class hours were used for homework. The thoughts proposed and ideas offered helped me with many issues. Since I did it with my friends, I took criticism in each stage of my material. I also had the chance to see the materials of my friends in their designing stage, not in their finished state [...]" (S6)

"The frustration of the homework before, the fact that not everyone worked in the group study, not being able to get together at the same time, the thought how I would do it were consuming me, and I was leaving to the homework to the last and doing homework of lower quality. But, with this method, there are different perspectives, idea exchanges and I receive help and support from my friends because everyone is working now. And I'm doing the homework gradually and not leaving to do it on the last day." (S20)

When it was asked to the students if they would find the flipped classroom method as an effective one and prefer it in appropriate subjects or classes when they would become teachers, 19 (76\%) of the students said they would prefer, 4 $(16 \%)$ said they would not prefer, and $2(8 \%)$ were neutral.

Finally, the participants made some recommendations so that videos prepared and the learning could be more effective. 
Students stated that the voice-footage synchronization should be noted in videos (S7, S8, S10 and S13) and the durations of videos should be shortened (S3 and S21). Moreover, they added that a setting closer to the classroom can be obtained if the instructor's full body is seen, not just his/her face, gestures and mimics along with the voice in the videos (S6 and S15) and if the courses are made more fun with small jokes (S7, S8 and S18). Some of the students emphasized the importance of the fact that they could ask questions immediately (S3, S4, S12, S19 and S24) and including different activities in the video or giving more applied homework after the subjects are taught would contribute to meaningful learning (S2, S3, S6, S16 and S21). A student emphasizing the social networking media where the instructor and students are together when watching the videos state the following sentences:

"A project like EasyClass can be applied. The issues that aren't understood in videos can be discussed with the entire classroom at that moment or can be asked to the teacher. This or other things should be thought for a more effective learning [...]." (S19)

\section{Discussion, Conclusion and Suggestions}

In this study performed in the Instructional Technologies and Material Development course of the second year at the elementary mathematics education program which aimed to investigate the effect of the flipped classroom method on students' academic achievement and motivation and determine the student opinions on the method, Basic Technology Competencies Scale for Educators Inventory was used to examine students' technological competencies and it was concluded that there was no significant difference between the groups. Moreover, it was revealed in accordance with the results obtained from Technological Perception Scale regarding the pretest-posttest score averages that there was no significant difference between the experimental and control groups in terms of their technological perceptions. Yet, it was seen that there was a significant difference between the groups in regard to academic achievement and motivation in favor of the experimental group. Consequently, it was found that the students educated with the flipped classroom method became more successful and had higher levels of motivation than the students educated with the traditional method. Indeed, Touchton (2015) states that the flipped classroom method increases the learning efficiency and yields results superior to traditional instructional methods. The reason for this result obtained in the study can be that learning environments enriched with technology have an impact on attracting student interest and curiosity further, facilitating the instruction and ensuring faster learning by making it more enjoyable (Yalın, 2003). The fact that the subjects can be flexibly examined whenever and wherever possible in the flipped classroom method may be included among the reasons for this result. In addition, how the flipped classroom method enabled the students and enhanced the discussions and interaction (student-student and teacher-student) in the classroom can be shown as a factor increasing the student motivation. This result indicates that the flipped classroom method can be used to increase achievement and motivation by facilitating the learning. In parallel with these results of the study, in their study performed in the physics class with 66 students who were attending at Department of Computer Education and Instructional Technologies, Aşıksoy and Özdamlı (2016) concluded that the students educated with traditional learning method had lower levels of motivation and achievement than the students educated with the flipped classroom method. Baepler, Walker and Driessen (2014) found as a result of the study they performed with the university students in the chemistry class that the flipped classroom method increased the student achievement. In another study, it was concluded that the group educated with the flipped classroom method was more successful than the group educated with the traditional method at Franklin University (Talbert, 2012). In contrast, Johnson and Renner (2012) concluded in their study in the computer applications course with the high school students that the flipped classroom method did not have any impact on the academic achievement. Davies, Dean and Ball (2013) found in their study aiming to determine how technology should be used to provide students with the skills related to technology in the Excel class that the flipped classroom method did not have any impact on the academic achievement but increased the student motivation.

It is necessary that video recording has a better quality and the video contents should be shorter and clearer to prevent students from distraction so that the subjects can be comprehended in an easier way in the flipped classroom method (Bergmann \& Sams, 2012; Miller, 2012; Milman, 2012). When examining the opinions on the videos prepared for the class hour; it was seen that the students agreed that the videos were suitable for the level, understandable and detailed. Yet, for one of the videos, it was emphasized that the synchronization in the video should be paid attention to and the length of the videos should be shortened. The reason may be that the students think they can understand the subjects better in this way. Bergmann and Sam (2012) emphasized that they made sure that the durations of the videos were between 10 and 15 minutes. Also, Miller (2012) stated that the durations of videos should be in accordance with the learning skills and levels of students. In consideration of the student levels, the duration of the videos was kept at 40 minutes. The reason why some of the students found the duration to be long may be that they did not create the suitable environment to watch the video, did not want to take much responsibility for their own learning because the videos required more effort to be understood, and there was no opportunity to ask questions to the peers or the teacher when watching the videos alone (Miller, 2012; Milman, 2012; Talbert, 2012). It is another recommendation from the students 
that it would be better if instructor's whole body was seen in the video in a way that his/her gestures and mimics can be watched, too, not only his/her face along with the voice. The reason for this recommendation could be that how the instructor would show his/her full body in videos would make the students feel belonged. Similarly, at the end of the study performed by Johnson (2013), the students recommended that the videos should be prepared rather in accordance with the interactive education. Moreover, making the classes more enjoyable with small jokes are among other recommendations. Since the students thought that the jokes would provide an environment closer to the classroom by preventing the course from being monotonous and preparing it as being interesting, they may have suggested that. If the recommendations of the students are taken into consideration, it can be said that the effectiveness of the flipped classroom method can be enhanced.

Providing students with learning environments in accordance with their individual paces independently from time and space (Davies, Dean \& Ball, 2013), increasing the communication between student and teacher, giving place to the cooperative activities in which students are active and allowing flexibility of time and space in learning are among the greatest advantages of the flipped classroom method (Kong, 2014; Strayer, 2012; Touchton, 2015). Bergmann and Sams (2012) stated that this method is not only about courses taught in the company of videos but its point of focus is also the meaningful and interactive activities performed in the classroom. In this study, it is seen that the most emphasized advantages of the flipped classroom method are "ensuring active participation", "enhancing student-teacher interaction", "being flexible in terms of time and space", "allowing repetitive watching", and "enhancing the peer interaction". In parallel with the findings obtained, Johnson (2013), Gençer (2015) and Turan (2015) mentioned about similar advantages in their studies. It is seen that another advantage emphasized by the students is "ensuring a permanent learning." Bergmann and Sams (2012) state that more applied activities can be performed in the flipped classroom method than the traditional method. This will provide more permanent learning for the students. Touchton (2015) addressed that the flipped classroom method enhances student learning and provide results superior to the traditional instructional methods.

In addition, "not being able to receive immediate feedback", "mitigating the student-teacher interaction", the responsibility of watching the videos before the class", "the fact that there is nothing to do in case of lack of instruments" and "limited time to prepare homework in the classroom" are other disadvantages emphasized by the students. It is seen that Milman (2012), Johnson (2013) and Turan and Göktaş (2015) mentioned about similar disadvantages in their studies. Students' responsibility of learning is one of the aspects of the flipped classroom method which is frequently emphasized in the literature (Bergmann \& Sam, 2012; Fautch, 2015; O'Flaherty \& Philips, 2015; Staker \& Horn, 2012; Talbert, 2012). The fact that some of the students found this aspect as disadvantage in this study can be explained by that the students accustomed to learn with traditional methods had difficulty to adopt the method because it formed a culture shock (Talbert, 2012). It can be said that the disadvantages such as not being able to ask teacher question and receive feedback at the moment can be eliminated by providing various social networking platforms. Indeed, one of the students highlighted the EasyClass platform as a solution for the problem in which the instructor and students could meet when watching the videos.

It was seen that the most prominent elements that increased the motivation were "desire to learn and curiosity", "being able to watch whenever and wherever possible", "doing practice", and "the fact that it can be used in the occupational life". Based on these findings, it can be said that applying and learning a new instructional method had positive impacts on the students. Students stated that the elements decreasing the motivation were "watching the videos individually", "not being able to ask questions immediately" and "long durations of video". It can be recommended that the duration of videos can be shortened because longer durations may cause students to get bored and distracted.

Lastly, it was found that majority of the students stated they would prefer the flipped classroom method when it was asked if they found it to be an effective method and prefer to use it in appropriate subjects or courses when they would become teachers. It can be said in accordance with the results obtained that the students had positive thoughts about the flipped classroom method and find this method as an effective and applicable. Johnson (2013) concluded that the students educated with the flipped classroom method reported that this method contributed to their learning and they enjoyed the courses. Moreover, Butt (2014) stated that the students educated with the flipped classroom method had more positive opinions in general. Gençer (2015) found that this method was accepted because it allowed students to be more active in the process, take the responsibility of their learning and spare more time to in-class activities.

In accordance with these results, different courses can be designed as to the flipped classroom method so that it can be investigated in which other fields this method can be used more efficiently. Moreover, creating several social networking platforms may allow the students to receive faster feedbacks. Not only pre-service teachers but also teachers and instructors can be informed of the benefits and applicability of this method. 


\section{References}

Abeysekera, L. \& Dawson, P. (2015). Motivation and cognitive load in the flipped classroom: definition, rationale and a call for research, Higher Education Research \& Development, 34(1), 1-14. https://doi.org/10.1080/07294360.2014.934336

Acar, S. (2009). The effect of ARCS motivational strategies on students' academic achievement, permanence, motivation and attitude of learning in web-aided performance-based learning. Unpublished master's thesis, Gazi University, Ankara.

Adıgüzel, A., \& Yüksel, İ. (2012). Evaluation of teachers’ instructional technologies integration skills: A Qualitative need analysis for new pedagogical approaches. Necatibey Faculty of Education Electronic J. Sci. Math. Edu., 6(1), 265-286.

Akpınar, E., \& Ergin, Ö. (2005). Yapılandırmacı kurama dayalı fen öğretimine yönelik bir uygulama / An application on the science teaching based on the constructivist theory. Hacettepe University Faculty of Education Journal, 29(29).

Alım, M. (2007). The importance of teaching technologies and material development course and suggestion on the teaching process. Doğu Coğrafya Dergisi, 12(17).

Asan, A. (2002). Pre-service teachers' use of technology to create instructional materials: A school-college partnership, Journal of Information Technology for Teacher Education, 11(2), $217-232$. https://doi.org/10.1080/14759390200200133

Aşçı, Z., Özkan, Ş., \& Tekkaya, C. (2001). Conceptual mistakes of students on the respiratory issue: a comparative study. Education and Science Journal, 26(120).

Aşıksoy, G., \& Özdamlı, F. (2016). Flipped classroom adapted to the ARCS model of motivation and applied to a physics course. Eurasia Journal of Mathematics, Science \& Technology Education, 12(6), 1589-1603.

Baepler, P., Walker, J. D., \& Driessen, M. (2014). It's not about seat time: Blending, flipping, and efficiency in active learning classrooms. Computers \& Education, 78, 227-236. https://doi.org/10.1016/j.compedu.2014.06.006

Bayram, H., Sökmen, N., \& Savc1, H. (1997). Identifying the readability of the basic concepts of sciences. $M$. $U$. Atatürk Faculty of Education Journal of Educational Sciences, 9, 89-100.

Bergmann, J., \& Sams, A. (2012). Flip your classroom: Reach every student in every class every day. Washington, D.C.: International Society for Technology in Education.

Bishop, J. L., \& Verleger, M. A. (2013, June). The flipped classroom: A survey of the research. ASEE National Conference Proceedings, Atlanta, GA, 30(9).

Butt, A. (2014). Student views on the use of a flipped classroom approach: Evidence from Australia. Business Education \& Accreditation, 6(1), 33.

Chen, Y., Wang, Y., \& Chen, N. S. (2014). Is FLIP enough? Or should we use the FLIPPED model instead? Computers \& Education, 79, 16-27. https://doi.org/10.1016/j.compedu.2014.07.004

Coştu, B., Ünal, S., \& Ayas, A. (2007). Using the real-life events in the education of sciences. Ahi Evran University Kirşehir Faculty of Education Journal, 8(1).

Davies, R. S., Dean, D. L., \& Ball, N. (2013). Flipping the classroom and instructional technology integration in a college-level information systems spreadsheet course. Educational Technology Research and Development, 61(4), 563-580. https://doi.org/10.1007/s11423-013-9305-6

Demiralay, R., \& Karataş, S. (2014). The model of course at home-homework at school Journal of Educational and Instructional Research, 3(3), 333-340.

Doğan, Y., \& Yilmaz, M. (2012). The use of instructional technologies in the science and technology course and examining the related factors. Adlyaman University Faculty of Education Journal, 2(3), 107-121.

Fautch, J. M. (2015). The flipped classroom for teaching organic chemistry in small classes: Is it effective? Chemistry Education Research and Practice, 16(1), 179-186. https://doi.org/10.1039/C4RP00230J

Gençer, B. G. (2015). A case study on applying the flipped classroom method at schools (Unpublished master's thesis). Bahçeşehir University, Istanbul.

Görü, D. T. (2015). Using the social media in instructional processes: learner opinions on the flipped learning approach, AUAd, 1(2), 24-48. 
Johnson, G. B. (2013). Student perceptions of the flipped classroom. Electronic Theses and Dissertations (ETDs) 2008.

Johnson, L. W., \& Renner, J. D. (2012). Effects of the flipped classroom model on a secondary computer applications course: Student and teacher perceptions, questions and student achievement. Unpublished $\mathrm{PhD}$ thesis, University of Louisville.

Kaya, H., \& Aydın, F. (2011). Students' views towards interactive white board applications in the teaching of geography themes in social knowledge lessons, Journal of World of Turks, 3(1), 179-189.

Kim, M. K., Kim, S. M., Khera, O., \& Getman, J. (2014). The experience of three flipped classrooms in an urban university: An exploration of design principles. The Internet and Higher Education, 22, 37-50. https://doi.org/10.1016/j.iheduc.2014.04.003

Kong, S. C. (2014). Developing information literacy and critical thinking skills through domain knowledge learning in digital classrooms: An experience of practicing flipped classroom strategy. Computers \& Education, 78, 160-173. https://doi.org/10.1016/j.compedu.2014.05.009

Küçükahmet, L. (2002). Planning and Evaluation in Instruction (13 ${ }^{\text {th }}$ Edition). Ankara: Nobel Yayın Dağıtım.

Miller, A. (2012). Five best practices for the flipped classroom. Edutopia. Posted Online, 24, 2-12.

Milman, N. B. (2012). The flipped classroom strategy: What is it and how can it best be used? Distance Learning, 9(3), 85 .

Ministry of National Education [MoNE] (2013). Secondary education $\left(9^{\text {th }}, 10^{\text {th }}, 11^{\text {th }}\right.$, and $12^{\text {th }}$ grades) mathematics curriculum, Ankara: Ministry of National Education Publication.

Moravec, M., Williams, A., Aguilar-Roca, N., \& O’Dowd, D. K. (2010). Learn before lecture: a strategy that improves learning outcomes in a large introductory biology class. CBE Life Sci. Edu., 9, 473-481. https://doi.org/10.1187/cbe.10-04-0063

O'Flaherty, J., \& Phillips, C. (2015). The use of flipped classrooms in higher education: A scoping review. The Internet and Higher Education, 25, 85-95. https://doi.org/10.1016/j.iheduc.2015.02.002

Osman, S., Jamaludin, R., \& Mokhtar, N. (2014). Flipped classroom and traditional classroom: Lecturer and student perceptions between two learning cultures, a case study at Malaysian polytechnic. International Education Research, 2(4), 16. https://doi.org/10.12735/ier.v2i4p16

Sarıtaş, T., \& Yıldız, Ö. (2015). Gamification in education and flipped classrooms. Akademic Informatics Conference, February 4-6, Anadolu University, Eskişehir.

Staker, H., \& Horn, M. B. (2012). Classifying K-12 Blended Learning. Innosight Institute.

Strayer, J. F. (2012). How learning in an inverted classroom influences cooperation, innovation and task orientation. Learning Environments Research, 15(2), 171-193. https://doi.org/10.1007/s10984-012-9108-4

Talbert, R. (2012). Inverted classroom. Colleagues, 9(1), 7.

Tarman, B., \& Baytak, A. (2011). The new role of technology in education: Social studies teacher candidates' perceptions. Gaziantep University Journal of Social Sciences, 10(2), 891-908

Taşçı, G., Yaman, M., \& Soran, H. (2010). Examining biology teachers' status of using new technologies in instruction. Hacettepe University Faculty of Education Journal, 38(38).

Tekinarslan, E. (2008). The validity and reliability study for the Basic Technology Competencies Scale for Educators Inventory. Electronic Journal of Social Sciences, 7(26).

Temizyürek, F., \& Ünlü, N. A. (2015). An example of using the technology as a material in language teaching: "Flipped Classroom". Bartin University Journal of Faculty of Education, 4(1), 64-72.

Tinmaz, H. (2004). An assessment of preservice teachers' technology perception in relation to their subject area (Unpublished master's thesis), Middle East Technical Universiy, Ankara.

Toptaş, V., Çelik, S., \& Karaca, E. T. (2012). Pedagogical materials use of primary grade teachers in mathematics education. İlkögrretim Online, 11(4).

Touchton, M. (2015). Flipping the classroom and student performance in advanced statistics: Evidence from a quasi-experiment. Journal of Political Science $\quad$ Education, 11(1), 28-44. https://doi.org/10.1080/15512169.2014.985105

Tucker, B. (2012). The flipped classroom. Education next, 12(1). 
Turan, Z. (2015). Evaluating the flipped classroom method and examining its effect on academic achievement, cognitive load, and motivation (Unpublished master's thesis). Atatürk University, Institute of Educational Sciences, Erzurum.

Turan, Z., \& Göktaş, Y. (2015). A new approach in higher education: student opinions on the flipped classroom method. Journal of Higher Education \& Science, 5(2). https://doi.org/10.5961/jhes.2015.118

Yalın, H. İ. (2003). Instructional technologies and material development. Ankara: Nobel Yayınları.

Yıldırım, A., \& Şimşek, H. (2006). Qualitative research methods in social sciences. Ankara: Seçkin Yayıncılık.

Zownorega, S. J. (2013). Effectiveness of flipping the classroom in a honors level, mechanics-based physics class. Master's Thesis. Eastern Illinois University. Paper 1155.

This work is licensed under a Creative Commons Attribution 3.0 License. 